\title{
Long-term results of functional endoscopic sinus surgery in children with chronic rhinosinusitis with nasal polyps
}

\author{
Marjolein Cornet ${ }^{1 *}$, Christos Georgalas ${ }^{2}$, Susanne Reinartz ${ }^{2}$, Wytske Fokkens ${ }^{2}$ \\ From 9th Symposium of Experimental Rhinology and Immunology of the Nose (SERIN 2013) \\ Leuven, Belgium. 21-23 March 2013
}

\section{Background}

Chronic rhinosinusitis with nasal polyps (CRSwNP) is rare in children and has a major impact on Quality of Life (QoL). Functional endoscopic sinus surgery (FESS) has proven to be an effective treatment, but it is still unclear what long term outcomes are in children with CRSwNP. Therefore the objective of this study was to assess long term results of FESS in children with CRSwNP.

\section{Methods}

In this combined prospective and retrospective study a QoL questionnaire was send to all children who received FESS because of CRSwNP between the year 2000 and 2010. Almost half of these children also filled in this questionnaire preoperatively. Primary outcome was $\mathrm{R}-\mathrm{SOM}$ score.

\section{Results}

44 Children underwent FESS. From 18 patients we also prospectively collected preoperative QoL questionnaires. The response rate was $82 \%(36 / 44)$ and mean follow-up period was 4.0 years $( \pm 2.9)$. The mean age at surgery was 13 years $( \pm 2.9)$. Of these children 9 had CF $(25 \%)$ and 10 children asthma (28\%). R-SOM scores showed a significant improvement both in general symptoms as well as several different domains when comparing preand postoperative questionnaires $(\mathrm{p}=0.04)$. Only $14 \%$ (5) of the patients needed a subsequent intervention. In children with CF this was 33\% (3/9).

${ }^{1}$ AMC, Amsterdam, the Netherlands

Full list of author information is available at the end of the article

\section{Conclusions}

This study demonstrates that long term results of FESS in children with CRSwNP are good. Overall QoL has improved significantly for the whole group, especially in nasal symptoms, showing that FESS is a good treatment in children with CRSwNP. Furthermore even children with CF show good results.

\section{Author details \\ 'AMC, Amsterdam, the Netherlands. ${ }^{2}$ AMC, ENT, Amsterdam, the Netherlands.}

Published: 16 July 2013

doi:10.1186/2045-7022-3-S2-P34

Cite this article as: Cornet et al: Long-term results of functional endoscopic sinus surgery in children with chronic rhinosinusitis with nasal polyps. Clinical and Translational Allergy 2013 3(Suppl 2):P34.

Submit your next manuscript to BioMed Central and take full advantage of:

- Convenient online submission

- Thorough peer review

- No space constraints or color figure charges

- Immediate publication on acceptance

- Inclusion in PubMed, CAS, Scopus and Google Scholar

- Research which is freely available for redistribution 